\title{
A CENTRALIDADE DO TRABALHO NA DETERMINAÇÃO DA MOBILIDADE TERRITORIAL DOS TRABALHADORES RURAIS
}

\author{
Ana Elizabeth Santos Alves ${ }^{1}$ \\ Miriam Cléa Coelho Almeida ${ }^{2}$
}

\section{RESUMO}

Esse artigo trata da centralidade do trabalho na determinação da mobilidade territorial dos trabalhadores. Para tanto, se utiliza das contribuições teóricas de autores marxistas acerca da relação metabólica homem/natureza no processo de humanização e as metamorfoses dessa relação com o trabalho produtivo para fins de valorização do capital. O conceito de "mobilidade do trabalho" foi fundamentado em Gaudemar (1977) que oferece uma densa análise sobre as vinculações dos deslocamentos territoriais com a ampliação da produtividade e lucratividade. A mobilidade do trabalho nesses termos ocorre pari passu com a mobilidade do capital e, nesse sentido, é controlada e dominada pelos mediadores do capital. Essa discussão teórica vem entrelaçada com as análises do papel da educação na formação do trabalhador para o trabalho produtivo e da realidade da mobilidade do trabalho no Brasil e, mais especificamente, com a mobilidade dos trabalhadores no Sudoeste baiano e no Planalto conquistense. Esse esforço permitiu entrever as implicações "invisíveis" da mobilidade territorial do trabalho no sentido campo - cidade em Vitória da Conquista, marcadas nas histórias de vida de mulheres e homens migrantes.

Palavras-chave: Trabalho; Mobilidade; Expropriação; Rural; Educação

\section{THE CENTRALITY OF WORK IN DETERMINING THE TERRITORIAL MOBILITY OF RURAL WORKERS}

\begin{abstract}
This article deals with the centrality of work in determining the territorial mobility of workers. For that, it uses the theoretical contributions of marxist authors regarding the metabolic relation man / nature in the process of humanization and the metamorphoses of this relation with productive work for the purposes of capital valorization. The concept of "labor mobility" was based on Gaudemar (1977) that offers a dense analysis of the linkages of territorial shifts with the increase of productivity and profitability. The mobility of labor in these terms occurs pari passu with the mobility of capital and, accordingly, is controlled and dominated by the mediators of capital. This theoretical discussion has been intertwined with the analysis of the role of education in the shaping the worker to productive work and the reality of labor mobility in Brazil and, more specifically, with the mobility of workers in Baiano Southwest and the conquistense Plateau. This effort allowed to glimpse of the "invisible" implications of territorial mobility of labor in the sense country - city in Vitória da Conquista, marked in the life stories of migrants women and men.
\end{abstract}

Keywords: Work; Mobility; Expropriation; Rural; Education 


\section{Introdução}

A expulsão sistemática dos camponeses das suas terras pela falta de alternativas tecnológicas e econômicas para manter as novas gerações não é uma história recente. A inter-relação entre propriedade, trabalho e família na agricultura camponesa no Brasil foi construída de modo geral "sob o signo da precariedade estrutural" (WANDERLEY, 2009, p. 168), sendo difícil para o grupo familiar o desenvolvimento do sistema clássico de reprodução geracional de subsistência. As formas de precariedade podem ser caracterizadas pela exploração familiar na venda da força de trabalho à grande propriedade, pelas migrações, pela seca no sertão nordestino ou esgotamento do solo nas colônias do sul. A saída (temporária ou definitiva) de migrantes do campo torna-se obrigatória, especialmente para os camponeses que detém a posse de um pequeno pedaço de terra, como garantia das condições de reprodução social.

Diante dessas afirmativas questiona-se: Que razões históricas explicam a continuidade do processo de expropriação do trabalho de homens e mulheres camponeses?

Assim, este artigo tem como objetivo refletir acerca da centralidade do trabalho na determinação da mobilidade territorial dos trabalhadores e o quanto esse deslocamento se articula com o processo de acumulação capitalista. Para tanto, se utiliza das contribuições teóricas de autores marxistas acerca da relação metabólica homem/natureza no processo de humanização e as metamorfoses dessa relação com o trabalho produtivo para fins de valorização do capital. O conceito de "mobilidade do trabalho" foi fundamentado em Gaudemar (1977), autor que oferece uma densa análise sobre as vinculações dos deslocamentos territoriais com a ampliação da produtividade e lucratividade do capital. A mobilidade do trabalho nesses termos ocorre pari passu com a mobilidade do capital e, nesse sentido, é controlada e dominada pelos mediadores do capital. Essa discussão teórica vem entrelaçada com as análises do papel da educação na formação do trabalhador para o trabalho produtivo e da realidade da mobilidade do trabalho no Brasil e, mais especificamente, com a mobilidade dos trabalhadores no Planalto conquistense, BA. Esse esforço permitiu entrever as implicações do processo de deslocamento territorial dos trabalhadores do campo que continuam indo em busca de trabalho em São Paulo e para a cidade de Vitória da Conquista, marcadas nas histórias de vida de homens e mulheres migrantes.

Nas seções que seguem, inicialmente apresentam-se de modo resumido o que é o trabalho, quais são as suas relações com o modo de produção capitalista e a expansão da produção capitalista no campo; em seguida, procura-se conceituar a categoria mobilidade do trabalho relacionando-a com as exigências do processo de acumulação; por último, realiza-se algumas análises baseadas em dados empíricos sobre a mobilidade do trabalho em Vitória da Conquista.

\section{O trabalho: da sobrevivência à acumulação capitalista}

O trabalho é uma categoria essencial na vida de mulheres e homens. É fonte de contentamento e é responsável pela produção dos meios que possibilitam a satisfação das coisas materiais essenciais, como comer, beber, vestir-se, e a produção da própria vida, que tem de ser cumprida diariamente, até hoje, para manter vivos os seres humanos. No seu sentido ontológico, significa "um processo entre o homem e a natureza, um processo em que o homem, por sua própria ação, media, regula e controla seu metabolismo com a natureza" (MARX, 1985, p.149), tornando-se um meio de produzir riqueza em geral, um 
processo de humanização. Essa noção de trabalho é entendida como um ato de criação do homem que ultrapassa a atividade instintiva dos animais, convertendo-se na força pela qual a humanidade criou o mundo tal como o conhecemos. A vida do ser humano é permeada por necessidades de sobrevivência e atividades de criação. Consequentemente, nesse plano mais abstrato, a categoria trabalho constitui-se "como fonte originária, primária, de realização do ser social" criadora de valores de uso (ANTUNES, 2001, p.167). A educação está interligada a esse processo. Começa com a labuta coletiva do dia a dia dos homens com a natureza e, à medida que vão aprendendo uma determinada atividade, ganhando experiência, vão educando os outros.

O trabalho, historicamente, assume diferentes formas e concepções. Na Antigüidade clássica, desenvolvia-se na relação entre escravos e servos e as classes aristocráticas, que detinham o poder da terra e a produção material dela advinda. O trabalho era concebido como "estigma fatal ou castigo", pois os homens por natureza eram tidos como desiguais (NOSELLA, 1989). Aristóteles (apud ARENDT, 1995) classificava três modos de vida segundo os quais o homem poderia viver: ocupar-se com o "belo", ou seja, coisas que não são necessariamente úteis; dedicar-se aos assuntos da polis; ou ter a vida do filósofo, que era de pura contemplação. O trabalho não era considerado digno para se constituir um modo de vida autenticamente humano, mas, sim, um instrumento de tortura - tripalium (deste termo latino, originou-se a palavra trabalho). Portanto, cabia ao escravo e o servo o exercício de diversas formas de trabalho forçado que garantiam a subsistência dos povos.

A partir do século XVII, o trabalho começa a tomar nova forma. O trabalhador passa da condição de escravo e servo para a de "homem livre". Com a invenção das máquinas, o homem tem a sensação de realizar o sonho de ver "finalmente reduzir a jornada de trabalho para transformar o homem escravo em cidadão político, culto e artista" (NOSELLA, 1989, p.320). A nova forma de trabalho libertou o trabalhador da escravidão, colocando-o no mercado para vender "livremente" a sua força de trabalho em troca de um salário. A era moderna trouxe o processo de fabricação, que é o trabalho do homo faber, criador de objetos na sua relação com a natureza. Essa relação do homem com a natureza tem como resultado o esforço coordenado e rítmico de fabricar objetos de uso, produzir mercadorias não apenas para uso privativo, mas, também, para serem comercializadas no mercado de troca. Nesse espaço, encontram-se os donos de mercadorias e de valores de troca. Com o crescimento da produção ostensiva, numa sociedade cuja troca de produtos é a principal atividade política, os donos da força de trabalho passam também a se oferecer como mercadorias no mercado de trocas, transformando toda a sociedade em uma sociedade operária, dando origem, assim, à formação da sociedade comercial ou capitalista (ARENDT, 1995).

Com o advento do capitalismo, a categoria trabalho deixa de ter a sua centralidade como valor de uso e se transforma em valor de troca tornando-o subordinado ao capital. As relações naturais e tradicionais entre as pessoas se mercantilizam. O indivíduo trabalha sob o controle do capitalista a quem pertence o seu trabalho, perdendo a propriedade dos meios e instrumentos e o produto do seu trabalho. A força de trabalho assume para o próprio trabalhador a forma de uma mercadoria, em razão do processo de apropriação e expropriação do trabalho. Homens e mulheres são alienados dos frutos produzidos por eles, constituindo em formas "estranhadas" ao trabalhador sob a determinação do capital. O trabalho se configura como trabalho alienado, manifestação de uma relação social fundada na propriedade privada, no capital e no dinheiro. O caráter histórico não-natural desse processo originado da apropriação privada do trabalho social, evidencia a contradição entre o capital e o trabalho. O entendimento do que é a educação nesse contexto é uma tarefa que deve ser explicada na contradição das possibilidades de emancipação do homem e as 
exigências do capital. A educação, por um lado, assume um papel de libertadora do homem quando ele transforma a natureza em coisas úteis segundo a sua vontade e como meio para a sua existência; por outro lado, é também a sua alienação que produz a desumanização no trabalho, principalmente com a divisão do trabalho industrial, quando o trabalhador reconhece os resultados do seu trabalho como algo independente, estranho (HEYDORN, 1968). A educação é submetida à capacitação técnica, política e ideológica determinada pelos interesses do capital.

Desse modo, o processo de valorização do capital ao capturar o trabalho e, ao mesmo tempo, subjugar o processo educativo cria as condições plenas para a sua expansão. As relações de produção capitalistas atingem todos os espaços sociais tanto no campo como na cidade, enriquecendo o capital por meio da superexploração da força de trabalho, pela extração de mais-valia no processo de produção e controle do processo de trabalho, fundamento da sociedade de classes e da dinâmica da luta de classes. A exploração ocorre pela produção do excedente no processo de troca das mercadorias que é controlada pelos capitalistas e é obscurecida pela aparente igualdade entre as classes. As relações sociais de poder entre os proprietários privados dos meios de produção e os vendedores de força de trabalho são históricas e efetivamente desiguais.

\section{As marcas da expansão da produção capitalista no campo brasileiro}

Na sociedade brasileira, a expansão das relações capitalistas de produção marca o início de um novo padrão de acumulação pós anos de 1930, com predominância da estrutura urbano-industrial e a consequente queda da hegemonia agrário-exportadora se apoiando no "enorme contingente de mão de obra, na oferta elástica de terras e na viabilização do encontro desses dois fatores pela ação do Estado construindo a infraestrutura, principalmente a rede rodoviária" (OLIVEIRA, 1981, p. 43)

O desenvolvimento capitalista na agricultura mantém a expansão parcial para o setor de exportação e para o mercado interno, a agricultura busca "suprir as necessidades das massas urbanas, para não elevar o custo da alimentação, principalmente e secundariamente o custo das matérias e não obstaculizar, portanto, o processo de acumulação urbanoindustrial" (idem, p.42). O crescimento econômico e social caminha de acordo com as exigências do "estilo urbano de vida" de uma classe média em expansão e do proletariado industrial.

O Estado teve o papel decisivo no processo de constituição da produção capitalista, ao introduzir um novo modo de acumular pela institucionalização das regras do jogo ligadas à expansão das atividades para o mercado interno. Oliveira (1981) destaca o papel da regulamentação das leis trabalhistas para os trabalhadores urbanos e a fixação do salário mínimo como fator primordial para o processo de acumulação e formação de um "exército de reserva" que afluía do campo para os centros urbanos. Destaca também a regulamentação de preços e de políticas de créditos favoráveis à indústria. Oliveira (1981) chama a atenção para o papel desempenhado pela agricultura naquele contexto: de um lado, tinha que suprir o setor de exportações para garantir a compra de bens de capital e consumo, e de outro, as necessidades das massas urbanas. No que diz respeito à produção de bens alimentícios, como feijão, arroz e milho, destinados ao consumo interno, incentivou-se a sua produção a custos baixos, para não encarecer o preço da alimentação e não inviabilizar a acumulação urbano-industrial, isso combinado com a expansão horizontal de novas terras pelos latifúndios para a criação de gado e a produção de bens de subsistência, reproduzindo uma "acumulação primitiva de capital". 
A trajetória da agricultura brasileira até os nossos dias é caracterizada pela manutenção, expansão e combinação de uma economia de subsistência com a agricultura modernizada, diante do desenvolvimento do capitalismo; entretanto, essas mudanças não se traduziram em uma regra geral para todos os contextos rurais, certos espaços conservam formas de organização tradicional, considerando a heterogeneidade cultura, social e econômica. (CARNEIRO, 1998; WANDERLEY, 2000). Ademais é importante destacar também que o desenvolvimento capitalista sempre se faz de modo desigual, heterogêneo e combinado.

A dinâmica do desenvolvimento da agricultura brasileira é dividida entre várias formas de agricultura familiar e latifúndios voltados para o agronegócio, marcado pelas contradições da expansão capitalista no campo. Ianni (2004, p. 104) ilustra as principais categorias ligadas as atividades agrícolas presentes no Brasil: fazendeiros e latifundiários, sitiantes posseiros, capatazes, arrendatários, parceiros, empreiteiros, colonos, agregados ou moradores, peões, camaradas, volantes, tratoristas, expressando diferentes formas de produtividade do trabalho e apropriação da força de trabalho. Essa realidade revela a presença de estruturas econômicas, predominando formas "tradicionais" de exploração do trabalho como "a economia de subsistência, o colonato ou os regimes tradicionais de arrendamento e parceria", ou em formas modernas que contam somente com o trabalho assalariado em dinheiro. Ao mesmo tempo, pode-se observar a expansão do agronegócio determinando as condições de geração e apropriação de sobretrabalho, de pequenos produtores e de trabalhadores assalariados, de caráter conservador e excludente (SILVA, 1998), determinado pelo modelo de "modernização conservadora" da agricultura brasileira.

Essa expansão está atrelada ao crescimento industrial, comercial e ao setor de serviços. Tal crescimento determinou os "movimentos migratórios" no sentido ruralurbano e intra-rurais, indo formar um "exército de reserva", proporcionando uma redefinição das relações capital-trabalho e a ampliação das possibilidades de acumulação industrial (OLIVEIRA, 1981, p. 46).

A intensidade desse deslocamento pode ser notada nos dados dos censos demográficos do IBGE de 1940 e 2010 os quais evidenciam a inversão da população residente do campo para as cidades. Em 1940 a população rural representava 69\% do total populacional e já em 1970 cai para $44 \%$ contra $56 \%$ da população urbana. Essa inversão se acentuou ainda mais nas décadas seguintes e está mantida ainda hoje, sendo $16 \%$ da população residindo no campo e $84 \%$ da população residindo em áreas urbanas. Convém ressaltar que as áreas urbanas que irão receber esse contingente populacional, coincidem exatamente com aquelas em que, concomitante, ocorre a concentração de capitais, a exemplo das regiões Sudeste e Sul com destaque para as capitais metropolitanas, São Paulo, Rio de Janeiro, Belo Horizonte, entre outras. Esses espaços urbanos abrigavam grande parte da atividade industrial brasileira e, ainda hoje, com a modernização da agricultura e a inserção de outras atividades econômicas continuam a ser um dos destinos vislumbrados pelos trabalhadores desempregados e pauperizados, apesar de, proporcionalmente, as cidades médias com população entre 100 e 500 mil habitantes, crescerem a taxas maiores que as das metrópoles nos anos de 1980 e 1990, respectivamente, 4,8\% contra 1,3\%, conforme dados do IPEA (1999).

Adverte-se, no entanto, que a constituição do "exército de reserva industrial" passou, sobretudo, pelo processo de expropriação camponesa resultante do projeto de modernização agrícola empreendido pelo Estado brasileiro e é exatamente essa massa de trabalhadores despossuídos que irá servir aos interesses da acumulação capitalista. Ao examinar a modernização da agricultura tendo como base o caso emblemático do Vale do 
Jequitinhonha - MG, Silva (1999) destaca a institucionalização e legalização da expropriação do campesinato pelo Estado,

A expropriação do campesinato do Vale do Jequitinhonha - MG é [...] resultante dos planos de modernização edificados durante os anos $1960 \mathrm{e}$ 1970, pelos governos da ditadura militar. De antemão, cabe dizer que, tal expropriação, culminando com a tomada das terras e destruição de parte do campesinato, não ocorreu, em sua quase totalidade, por intermédio da violência aberta, mas, ao contrário, da violência escondida e legal, ou seja, da violência monopolizada pelo Estado, com a promulgação de leis que implementaram os projetos de modernização nesta região (SILVA,1999, p. 27).

Soma-se a isso, o fato de que a apropriação de terras no Brasil se dá (com exceção das que seriam títulos de sesmarias ou outros) com a compra e venda e, portanto, a propriedade da terra "vai depender do poder de compra dos futuros proprietários. É por meio deste monopólio que a expropriação de posseiros e a não-regulamentação das posses serão atos do direito público" (SILVA, 1999, p.30) e, ao mesmo tempo, viabilizam o controle do Estado na apropriação de terras no Brasil, vez que este teria a propriedade de todas as terras devolutas.

É por essa razão que para Silva, "a propriedade privada das terras [...] só foi assegurada pelo Estado, por meio da venda das terras devolutas e, consequentemente de sua legitimação ou reconhecimento pelo poder público" (p.33). Desse modo, qualquer outra forma de apropriação que não fossem nesses moldes era considerada devoluta. Essas condições revelam que "por detrás da aparência de igualdade de direitos a todos, impunhase a necessidade da legitimação pelo poder público. É justamente esta imposição que esconde a violência da tomada das terras dos camponeses pobres dentro da lei e da ordem" (SILVA, 1999, p.33).

Se se considerar que nesse contexto histórico de criação da Lei das Terras no Brasil (1850), tem-se a intensificação da imigração de trabalhadores estrangeiros, cuja força de trabalho seria destinada às lavouras de café e aos trabalhadores nacionais empobrecidos, a fixação do valor da terra pelo Estado deveria ser superior ao poder de compra desses trabalhadores, impossibilitando a sua compra.

Nessa perspectiva, serão os grandes proprietários e empresas do agronegócio que irão deter o poder de compra das terras, restando aos camponeses apenas a venda de sua pequena propriedade, ou, como em muitos casos, a retirada à força do seu "torrão" para um destino incerto. No caso do Vale do Jequitinhonha "as terras compradas foram, em seguida, revendidas às grandes companhias, como se pode depreender dos registros de compra e venda. Nesta venda, ocorreram as retificações de área, um ardil jurídico para disfarçar o roubo das terras dos camponeses pobres" (SILVA, 1999, p. 47). É com base nessas constatações que Silva afirma que "[...] a terra de negócio ao substituir a terra de trabalho [...] provoca, além da expropriação objetiva, a expropriação simbólica" (p. 47).

Ao tratar da acumulação primitiva e realizar uma análise do processo brutal de expropriação da população primitiva na Inglaterra, Marx já alertava ao concluir que “[...] conquistaram a terra para a agricultura capitalista, incorporaram o solo ao capital e entregaram à indústria das cidades os braços dóceis de um proletariado sem lar nem pão" (1989, p.55). 
É nesse sentido que o processo de expropriação dos camponeses é, então, entendido como um dos principais responsáveis pelo deslocamento dos trabalhadores do campo para a cidade e representa um perverso processo social de produção de miseráveis a serviço do capital. A migração é assim um "componente do processo de expropriação, desenraizamento e proletarização do camponês” (MARTINS, 2012, p. 45). Desestrutura o universo das relações pessoais do indivíduo "para lançá-lo no mundo das relações igualitárias e contratuais" (idem) ao assumir a condição operária seja no espaço agrário ou no urbano. Associa-se a isso o fato de que, ao se tornarem proletários, os trabalhadores perdem a sua autonomia no processo de trabalho e submetem o seu "saber fazer" ao processo educativo imposto pela divisão capitalista do trabalho cuja função é "educar" o trabalhador para o exercício de suas atividades, de modo tal que essa educação não se converta, mais tarde, em libertação. É com base nesses pressupostos que a população migrante miserável desempenha uma tarefa primordial aos propósitos da acumulação do capital, na medida em que serve para controlar os salários e submeter os dóceis/"educados" trabalhadores ocupados as mais cruéis formas de exploração da sua força de trabalho.

No Brasil, desde o período colonial, o fluxo de trabalhadores expropriados é criado, estimulado, controlado ou refreado para atender aos interesses do capital, tendo o Estado e as grandes empresas capitalistas nacionais ou transnacionais como suas principais personificações. O desenvolvimento econômico brasileiro é marcado pelas diversas ações estatais para impulsionar o desenvolvimento de determinadas regiões, ora para fortalecer as fronteiras agrícolas para estimular o agronegócio ou para intensificar a produção e lucratividade das regiões industriais. Desde o período colonial, grosso modo, têm-se os Ciclos da Cana-de-açúcar (1532), Mineração (1709-1789), Café (1800-1930), Borracha (1866-1913), Soja (1970) e Industrialização (1945). Em todos esses momentos econômicos viu-se, e ainda hoje se vê, uma intensa mobilização de força de trabalho, sobretudo, de trabalhadores empobrecidos povoando as estradas brasileiras em busca de sua sobrevivência.

Ademais, junta-se às estratégias econômicas as ações de ordem geopolítica do governo brasileiro a exemplo do Plano de Integração Nacional (PIN) criado em 1970 com o objetivo de utilizar a força de trabalho dos nordestinos "fugitivos da seca" nos espaços considerados "vazios demográficos" na Amazônia e promover a ocupação e seguridade dessas áreas. A Rodovia Transamazônica é talvez a iniciativa mais perversa de "colonização" do governo brasileiro. Igualmente expressivas são as construções da capital federal Brasília, o Projeto Carajás, entre outros.

Se se toma o quadro atual dos deslocamentos territoriais brasileiros, observa-se que os princípios da produtividade e lucratividade foram mantidos, mas as estratégias foram aprimoradas e as rotas redefinidas de modo a qualificar e acelerar os ganhos do capital. Nesse sentido, o fato desses deslocamentos acompanharem e estarem à serviço do processo produtivo nos obriga a verter um pouco mais sobre as vinculações entre a mobilidade do trabalho e a mobilidade do capital.

\section{Mobilidade do trabalho e mobilidade do capital}

A mobilidade do trabalho como categoria analítica não é recente e tem sido alvo de estudos desde que os constantes deslocamentos territoriais, em diferentes escalas, exigiram um aprofundamento das motivações e engrenagens que determinavam as suas bases.

As análises seguem múltiplas interpretações ora em conformidade com o determinismo ambiental, ora com o processo de acumulação do capital. Como se pode 
perceber em linhas anteriores, nessa abordagem se distancia das concepções que naturalizam os deslocamentos populacionais e os justificam com base no crescimento natural da população e nas adversidades ambientais entendidas como as responsáveis pelo desequilíbrio da ocupação da superfície terrestre e pela constituição das áreas ecúmenas e anecúmenas do globo terrestre. Entende-se que essas ideias foram e ainda são muito úteis ao capital para justificar a separação dos trabalhadores dos meios de subsistência e de produção, a expansão do desemprego e a movimentação territorial, sobretudo, no sentido rural-urbano.

Isto posto, filia-se à perspectiva teórica que insere os deslocamentos territoriais no processo geral da acumulação capitalista, e, portanto, articulados com a mobilidade do capital. Logo, trata-se da mobilidade do trabalho como uma categoria que, de acordo com Gaudemar (1977 apud GOMES, 2009, p. 38), "busca compreender como se estabelece a produção da força de trabalho como mercadoria, seu consumo de forma intensiva e extensiva, bem como essa força de trabalho é mobilizada em termos espaciais, setoriais e profissionais". E ainda averiguar "por que razão se presta o trabalho, ou antes, a força de trabalho dos homens a todas as variações de duração, intensidade, produtividade, que levam ao nascimento da mais-valia tanto sob a sua forma absoluta como relativa" (GAUDEMAR, 1977, p. 14)

Nessa direção, o autor diverge da concepção de que a mobilidade do trabalho se constituiria em apenas um deslocamento espacial dos homens, para então colocar no centro do debate a mobilidade do trabalho como "[...] o uso capitalista das disponibilidades dos homens, da docilidade (Foucault) dos seus corpos" (GAUDEMAR, 1977, p.17).

São esses pressupostos que impelem Gaudemar (1977) à afirmação:

Com a mobilidade do trabalho manifesta-se sempre o modo como os homens submetem o seu comportamento às exigências do crescimento capitalista. Toda a estratégia capitalista de mobilidade é igualmente estratégia de mobilidade forçada em prol da valorização do capital (p. 17).

Ao aproximar essa iluminação teórica à realidade objetiva produzida pelo desenvolvimento das forças capitalistas de produção no contexto brasileiro vê-se que as migrações sempre estiveram a serviço da valorização e expansão do capital. O controle dos fluxos pelo Estado e pelo capital esteve presente nas diferentes fases do desenvolvimento econômico brasileiro e se mantem ainda hoje. Esse comportamento é notado nos momentos em que o indutor ora estimula o fluxo ora reage contra ele, de modo a atender aos seus interesses.

Essa tendência, como visto, foi reforçada pelo modelo de desenvolvimento agroindustrial brasileiro que se baseava, sobretudo, na ampliação das propriedades fundiárias, na monocultura e na expropriação camponesa. Esse processo resultou na produção de uma massa trabalhadora disponível que se constituiriam numa reserva possível de ser utilizada, a qualquer momento, pelo capital para ampliar a sua valorização e expansão.

Assim os trabalhadores expropriados e empobrecidos eram mobilizados de uma região para outra, vulneráveis às diversas formas de exploração e dominação que marcaram a expansão do capitalismo no Brasil.

$\mathrm{Na}$ avaliação de Martins (apud DAMIANI, 2001, p. 19) 
[...] essa criação de excedentes populacionais úteis não se faz só na fábrica, e não expressa somente exploração. Significa também dominação e exclusão econômica e política. Sob esse prisma, podemos compreender outras camadas ou classes subalternas que participam do processo de desenvolvimento capitalista, mesmo não estando integradas diretamente no processo de trabalho capitalista - como os camponeses; ou, como os peões, vivendo relações clandestinas de trabalho, praticamente escravizados, em muitas regiões brasileiras.

No sudoeste baiano e, mais especificamente, no Planalto Conquistense esse processo também foi marcado pela expropriação e dominação de trabalhadores que, sem alternativa, perderam suas terras e seus meios de subsistência e se sujeitaram ao trabalho assalariado tanto no campo como na cidade, como se verá adiante.

\section{A mobilidade do trabalho em Vitória da Conquista}

O desenvolvimento das relações capitalista de produção no município de Vitória da Conquista ocorre, sobretudo, com a expansão da cafeicultura no Planalto Conquistense a partir da década de 1970. A atividade cafeeira inserida no processo de valorização do capital, logo, ao processo de produção de mercadorias trouxe em seu bojo uma série de desdobramentos dentre eles destacam-se a ampliação da extensão das propriedades rurais, a adoção de novos meios de produção a exemplo do uso de novas forças produtivas (introdução de máquinas e implementos agrícolas) que dispensaram grande parte da força de trabalho e, consequentemente, produziram a expropriação e expulsão dos trabalhadores rurais, os quais sem alternativa foram forçados à mobilidade para as cidades da região.

A mobilidade do trabalho resultante desse processo pode ser notada ao examinar o comportamento da dinâmica demográfica de Vitória da Conquista entre as décadas de 1960 e 2010. Conforme os dados censitários do Instituto Brasileiro de Geografia e Estatística (IBGE), em 1960 a população total do município era de 48.712 habitantes, em 1980 foi para 127.454, em 2000 saltou para 262.494 habitantes e em 2010 já se somavam 306.374. Desse total de 2010, 274.805 residem em áreas urbanas, o que corresponde a 90\% dos habitantes e 31.569 residem na área rural, ou seja, apenas $10 \%$ da população permanece no campo. Se se considerar que na década de $1940,74,3 \%$ dos habitantes viviam no campo e em 2010 são apenas $10 \%$ isso mostra que a realidade municipal segue a tendência nacional de intensa concentração populacional no espaço urbano.

Entretanto, a análise dessa mobilidade não pode desconsiderar a mobilidade do capital e a relação de complementariedade entre campo e cidade, bem com as estratégias do capital para ajustar e equilibrar os fluxos migratórios de modo a atender aos seus interesses. A chegada dos trabalhadores rurais no espaço urbano de Vitória da Conquista cria as condições para a produção e reprodução ampliada do capital, cujas marcas estão impressas na desigualdade socioespacial de seus contornos territoriais.

Essas constatações corroboram as proposições de Gaudemar (1977, p. 19), ao identificar os três objetivos do governo e do patronato com a mobilidade: "[...] mobilizar a mão de obra, dinamizá-la, saber reconvertê-la". Esses objetivos atendem ao propósito capitalista de dominação dos fluxos de modo a garantir maior produtividade e lucratividade, pois, ainda segundo esse autor, "Só interessam ao capital aquelas que asseguram a sua valorização, quer correspondam a uma intensificação ou a uma 
produtivização acrescidas, do trabalho, quer se dirijam para os espaços da polarização capitalista próprios para os absorver" (1977, p. 19).

A mobilidade campo-cidade se enquadra muito bem nessa estratégia capitalista e, em Vitória da Conquista, essa transferência da população do campo para a sede municipal também cumpriu ao propósito da acumulação do capital, pois não trouxe consigo a melhoria da qualidade de vida dos trabalhadores, mas a produção de um espaço urbano adequado à livre produção e circulação das mercadorias. E, nesse processo, a mobilidade forçada submeteu os trabalhadores às formas exploratórias, à precarização com péssimas condições de trabalho e ao assalariamento. Ao analisarem os desdobramentos do avanço capitalista no campo conquistense Souza e Santos (2011, p. 6-7) destacam que

O avanço das relações capitalistas no campo repercute nas relações de trabalho desenvolvidas até então, pois ao passo em que, em determinados locais, permite uma convivência com as relações de produção nãocapitalistas (que predomina, sobretudo, nas áreas de caatinga, que tiveram de forma menos direta o processo de modernização vinculada à expansão cafeeira), no geral o que se assiste é o crescimento das relações capitalistas de produção e a difusão do trabalho assalariado, mediante a conversão do camponês em trabalhador assalariado.

Essa sujeição do trabalhador à mobilidade forçada é justificada por Gaudemar (1977) pelo fato de que "[...] o trabalhador não tem diante de si outra hipótese que não seja vender ou não a sua força de trabalho; não tem mais nada para vender, e na prática, ou vende a sua força de trabalho para viver, ou não a vende e morre" (p. 190). Apesar da força de trabalho ser livre e o trabalhador ser considerado como "actor de sua própria liberdade" não se pode esquecer que o mesmo tem "absoluta necessidade de a vender" (p. 190). É com base nesses pressupostos que se desenvolve e visualiza a mobilidade capitalista do trabalho que, ainda citando Gaudemar, "[...] a mobilidade da força de trabalho é assim introduzida em primeiro lugar, como a condição de exercício da sua "liberdade" de se deixar sujeitar ao capital de se tornar a mercadoria cujo consumo criará o calor e assim produzirá o capital" (1977, p. 190).

Estudos recentes sobre a mobilidade do trabalho no Sudoeste baiano e no Planalto Conquistense, tendo a cidade de Vitória da Conquista como o principal espaço receptor da força de trabalho migrante em função da sua condição de centralidade regional, revelam as condições objetivas dos trabalhadores precarizados e a destrutividade da acumulação capitalista.

Ao analisar a história de vida de trabalhadores desempregados em acampamentos e assentamentos em Vitória da Conquista, Menezes constata:

A mobilidade de suas vidas, nos atuais tempos de crise, passa a não ser mais determinada, como outrora foi, pela fuga da miséria e a esperança de uma vida melhor a partir da "conquista" de um emprego mais gratificante, mas agora única e exclusivamente pela sobrevivência, para somente fugir da miséria. As esperanças se perderam com a crise: um lugar melhor é um lugar menos miserável (2011, p. 205).

E ainda enfatiza que "a história de vida dos trabalhadores, como dos desempregados do MTD, é o próprio resumo da história desrealizativa do trabalho no metabolismo do capital" (MENEZES, 2011, p. 213). 
As análises dos pesquisadores do Projeto de pesquisa: "Formação e divisão sexual do trabalho em unidades de produção tradicional rural"3, com base nos depoimentos colhidos de moradores da zona rural do município de Planalto - BA, os quais evidenciam as suas histórias de vida, também atestam a mobilidade forçada do trabalho como se verá nos depoimentos que se seguem.

A história de vida de um camponês que mora na comunidade rural de Jacó e trabalha em São Paulo como servente de pedreiro é bem reveladora:

[...] sempre eu trabalho mais pra fora, pra São Paulo, aqui eu quase não trabalho não. Fico um tempo aqui, passo outro lá, é assim, trabalho um ano aqui, três lá, é assim. Tem uns 30 dias que eu cheguei. A renda aqui é pouca senhora, não tem nem como calcular a renda que a gente tem aqui de roça não, roça totalmente, a gente num ta quase fazendo roça assim de lavoura de pranta, porque a chuva ta escassa, a gente pranta os trem morre tudo, alguma vez a gente pode fazer uma rocinha assim, a gente pranta um capinzinho, lavoura assim a gente não pode nem calcular. [...] Aqui na diária aqui a gente trabalha, trabalha um dia, trabalha uma semana, as vezes trabalha duas semana e fica um mês parado, ou até mais. Ai a gente vai batalhando devagarzinho né. O que a gente tem foi batalhando fora [...] eu fico aqui um ano, dois anos, vou lá e fíco um ano, oito meses, a gente vai ficando assim [...] (Entrevista realizada em 05/10/2013).

As revelações desse camponês deixam entrever que apesar das dificuldades enfrentadas diariamente no campo, as experiências vivenciadas com o trabalho no espaço urbano não extinguem o apego e o desejo de retorno ao campo. A relação umbilical que as famílias camponesas estabelecem com a terra, os vínculos com parentes e com os vizinhos por meio do compadrio, ainda resistem à imperatividade do capital. Todavia, isso nem sempre é possível, pois infelizmente a migração do trabalho do camponês quase sempre destrói as relações familiares e demonstra a pobreza daquele que não tem condição de garantir a sua sobrevivência e da família, diante da limitação da reprodução para as futuras gerações do pequeno lote agrícola. É obrigado a vender a sua força de trabalho como boia fria nas plantações de cana de açúcar ou para setores industriais na cidade, a exemplo da construção civil, como indicado no depoimento em apreço.

Já as histórias de vida das mulheres moradoras das comunidades rurais exemplificam o "esparrame" das famílias que ao completarem a idade adulta partem em busca de trabalho:

[...] eu nasci, criei e casei aqui casei com dezoito anos e depois de um ano de casada eu fui morar em São Paulo morei dezoito anos lá daí eu voltei pra qui como eu tinha muito problema alérgico lá, aí eu voltei cheguei aqui eu fui ficando aí eu não quis voltar mais pra lá acabei vendendo minha casa lá e construi aqui. Eu tenho nós somos em oito irmãos, faleceu um, ficou sete, meus irmãos mora todos em São Paulo. Só tem uma irmã aqui agora que tá cuidando do meu pai. [...] depois que ficaro adulto, casaram aí foi embora [...] eu fui, eu casei construi a casa e fui pra São Paulo [...] lá eu trabalhava de doméstica, de vendedora autônoma. Trabalhava com produto de iaqute, Nestlé. Dezoito anos [...] depois voltei, agora tá com cinco anos que eu voltei. Meu filho que mora aqui, 
[...] ele trabalha em Vitória da Conquista. Ele é pedreiro. [...] vai e volta, todo final de semana. Trabalha na semana e volta no final de semana (Entrevista realizada em 12/06/2012).

[...] doze filhos [...] tá quase tudo ni São Paulo [...] É uns trabalhando, uns já mora lá e outros trabalhando. [...] trabalha ni obra, ni firma, ni restaurante, essas coisa assim. [...] é, mora aqui nessa casinha, mas agora ele tá em São Paulo. Tem um ano que ele tá lá, mais de ano, ele e a mulher tá lá, tá trabalhando pra vim embora, é pra vim embora. [...] É vem morar aqui, ele mora aí nessa casa aí. [...] ele trabalha, acho que é de ferreiro, ni obra né (Entrevista realizada em 02/07/2012).

É curioso notar nos depoimentos a referência ao trabalho na construção civil, seja em Vitória da Conquista ou em outros destinos a exemplo de São Paulo, como a principal ocupação dos trabalhadores. Sampaio (2013) também ao examinar a mobilidade do trabalho e a produção do espaço regional de Vitória da Conquista, e, mais especificamente, as ocupações da população que trabalha em Vitória da Conquista e mora em municípios vizinhos, constatou que entre os trabalhadores migrantes a profissão de pedreiro ocupa o primeiro lugar com $25 \%$ do total das ocupações. Para a autora,

A profissão de pedreiro ressalta o crescimento da construção civil na cidade e a necessidade das construtoras de contratar mão-deobra de fora. Esses pedreiros vêm de municípios vizinhos e desenvolvem também a função de mestre de obras. Do município de Barra do Choça, os trabalhadores saem pela manhã em caminhões para o serviço na construção civil em Vitória da Conquista e retomam à tarde. Segundo uma construtora da cidade, os pedreiros são das cidades de Poções, Planalto, Barra do Choça, Cândido Sales, Bom Jesus da Serra e Boa Nova (SAMPAIO, 2013, p.194-195).

Embora não seja o objetivo desse artigo aprofundar essa discussão, entende-se que para compreender as razões pelas quais milhares de trabalhadores buscam a construção civil como meio de sobrevivência é fundamental conhecer a evolução do processo de trabalho nesse setor econômico e, mais que isso, pensar na sua associação ao processo geral de valorização e, portanto, ao processo de produção capitalista gerador de mercadorias.

Essa vinculação faz com que o processo de trabalho na atividade construtiva acompanhe as mutações ocorridas nas diferentes fases da acumulação capitalista e, por essa razão, é submetido a alterações frequentes em seus meios de produção e nas funções ou tipo de trabalho ai realizados. Essas modificações, por sua vez, também requerem trabalhadores capazes de atender às novas exigências postas pela reestruturação produtiva. Por esta razão, a educação capitalista terá um papel importante na formação desse trabalhador, daí a advertência de Frigottto:

Na perspectiva das classes dominantes, historicamente, a educação dos diferentes grupos sociais de trabalhadores, deve dar-se a fim de habilitálos, técnica, social e ideologicamente para o trabalho. Trata-se de 
subordinar a função social da educação de forma controlada para responder às demandas do capital (FRIGOTTO, 1995, p.26)

Ou, como na avaliação de HEYDORN (1968) “[...] a educação capitalista visa revolucionar as atividades produtivas - revolução na base material - enquanto busca impedir a revolução na consciência. Esta contradição deve ser bem explorada; ela precisa tornar-se consciente já no realismo educativo capitalista" (p.122). O comprometimento da educação na formação profissional para o atendimento ao mercado de trabalho é bastante evidente na realidade brasileira.

Vê-se, então, que o dinamismo registrado no setor da construção civil está eivado de contradições, as quais precisam ser melhor analisadas. No Brasil, estudos apontam que o processo de valorização do capital na construção civil tem se traduzido em intensa exploração e precarização das condições e relações de trabalho.

Desde as décadas de 1970 e 1980 a exploração e a precarização já marcavam as condições e relações de trabalho na construção civil brasileira. Segundo Vargas (1992) o processo de expulsão da população do campo fez com que a força de trabalho nesse setor fosse, majoritariamente, rural e representava para o conjunto dos trabalhadores a sua sobrevivência face às péssimas condições de trabalho no campo. Para Vargas (1992, p. 47), "[...] esse processo garantiu uma mão de obra abundante, pouco acostumada à disciplina industrial e com pouca formação escolar. O setor, para ela, era uma sobrevivência".

Ainda de acordo com os estudos de Vargas (1992, p. 47),

Essas características criaram no setor uma visão de que o "peão" não tinha nenhuma preocupação em se fixar, seja na empresa, seja na cidade onde trabalhava, pois ainda estava vinculado à terra natal. A palavra "peão" atendia, assim, a um duplo sentido: aquele que gira e a origem rural.

Essa realidade objetiva referenda a tese já esboçada de que a mobilidade do trabalho sempre esteve articulada com a mobilidade do capital. E, nesse sentido, a análise dos comportamentos migratórios, em qualquer que seja a direção (campo-cidade; cidadecampo; cidade-cidade; campo-campo; entre outras), deve levar em consideração o controle social exercido sobre a força de trabalho em prol de maior lucratividade.

É essa compreensão que nos permite explicar por que apesar da permanência de uma força de trabalho pouco qualificada ou pouco acostumada com o trabalho industrial assiste-se a ascensão da construção civil, sobretudo, com a introdução das inovações tecnológicas e organizacionais no processo de trabalho, bem como o volume de investimentos no setor que revitalizam os meios de produção para garantir maior produtividade e valor sobre os produtos.

No caso específico da construção civil, as características do setor, em geral, mostram que a inserção de tecnologias e as formas de organização do trabalho, exigidas pela reestruturação do capital na fase atual de acumulação, por um lado dinamizaram e intensificaram a produção e exigiram, cada vez mais, maior eficiência (com o aumento da produtividade, com a redução de prazos de execução e com a redução de custos da produção que quase sempre comprometem a qualidade do produto com o uso de materiais de baixa qualidade) e, por outro, reduziram os custos com a força de trabalho, sobretudo, pela subcontratação, com a ausência de vínculo empregatício, com a redução dos custos com segurança e benefícios para o trabalhador. Assegura-se com esses procedimentos a 
extração da mais-valia e, portanto, maior lucratividade às custas da informalidade e da precarização do trabalho.

Essas mudanças no processo de trabalho afetaram em cheio a autonomia "operária" na condução do trabalho e o "saber fazer" de ofício, características da construção tradicional. A perda de controle do processo de trabalho deve-se, dentre outros aspectos, à separação concepção-execução ainda muito presente no setor de construção civil.

Essa captura do trabalhador por meio da padronização e homogeneização das ações e do pensamento em prol do capital, fragmentando-os não só objetiva, mas também subjetivamente, já estava apontada por Lukács (1978, p. 100) ao avaliar as implicações do taylorismo. Segundo o referido autor:

[...] essa mecanização racional penetra até a "alma" do trabalhador: até suas propriedades psicológicas são separadas do conjunto da sua personalidade e objetivadas em relação a esta para poderem ser integradas em sistemas racionais especiais e reduzidas ao conceito calculador.

A superação dessas contradições presentes no desenvolvimento da construção civil, conforme aponta Farah (1996, p. 45) requer, de um lado, "resgatar a autonomia operária" e, do outro, "adquirir maior autonomia com relação às qualificações tradicionais". Mesmo considerando essas alternativas antagônicas, para Farah (1996, p. 45) elas se articulam e podem se constituir no "[...] embrião de novas formas de gestão de trabalho, que combinam a melhoria das condições de trabalho à participação dos trabalhadores no controle do processo de trabalho". Acredita-se ainda que a retomada da consciência por meio de uma educação libertadora é a estratégia mais viável para a emancipação dos trabalhadores.

Pelo exposto, verifica-se que a história dos trabalhadores migrantes bem como as condições materiais a que estão submetidos corroboram a tese de que a mobilidade do trabalho, sobretudo, dos trabalhadores pauperizados no Sudoeste baiano e no Planalto conquistense, se constitui numa importante estratégia do capital para garantir a realização de seus propósitos, mesmo que para isso, submeta uma massa de trabalhadores miseráveis a seu serviço.

\section{Considerações Finais}

A história dos deslocamentos territoriais no Brasil não pode ser analisada dissociada do processo de expropriação dos camponeses que, criou a massa de trabalhadores disponíveis à acumulação capitalista. A produção da miséria foi (e ainda é), portanto, fundamental para garantir a regulação dos salários e a submissão dos trabalhadores às diferentes formas exploratórias nos postos de emprego e, com isso, acelerar a extração da mais valia. Em todos os fluxos migratórios, com maior ou menor intensidade, o objetivo pleiteado é a ampliação da produtividade e lucratividade, nunca a melhoria das condições de vida dos trabalhadores. Ao contrário, pesquisas mostram a quantidade de trabalhadores mutilados e "encostados" em decorrência dos acidentes de trabalho. Além disso, as relações familiares são destruídas e o sonho de uma "vida melhor" se resume na luta pela sobrevivência. 
A educação capitalista teve um papel preponderante na formação de uma massa de trabalhadores e trabalhadoras aptas ao trabalho produtivo, cujos resultados se revertem em sua alienação e estranhamento. Para ultrapassar essa condição considera-se fundamental pensar numa educação libertadora para além do capital, de modo a permitir a retomada da consciência do sentido do trabalho pelos trabalhadores.

Em Vitória da Conquista, a história da mobilidade do trabalho andou nos mesmos trilhos. A análise da mobilidade de trabalhadores rurais do Sudoeste baiano e do Planalto Conquistense em direção à sede municipal conquistense reafirma a centralidade do trabalho na determinação da mobilidade territorial de mulheres e homens migrantes. A transformação desses seres humanos em apenas vendedores da força de trabalho, que se tornou mercadoria no processo de valorização do capital, faz com que a mobilidade do trabalho signifique o desenraizamento e a destruição da vida de milhares de trabalhadores, seja no campo ou na cidade.

A dominação e o controle da mobilidade do trabalho pelo capital, personificado no Estado e nas grandes empresas, traçam, previamente, os destinos dos trabalhadores rurais rumo à exploração e precarização nas diversas atividades econômicas e, mais fortemente, na construção civil. Esse setor econômico se configura como o maior receptor da força de trabalho migrante por oferecer postos de baixa qualificação que não exigem prática no trabalho industrial e, em geral, por possuir uma base tecnológica dependente de "muitos braços". Apesar disso, contraditoriamente, assiste-se à ascensão da construção civil, sobretudo, com a introdução das inovações tecnológicas e organizacionais no processo de trabalho, bem como o volume de investimentos no setor que revitalizam os meios de produção para garantir maior produtividade e valor sobre os produtos. Ao passo que os seus trabalhadores vivem expostos a uma dura rotina de trabalho e a perversas formas de exploração.

Em geral, nota-se a engenhosidade do capital para realizar os seus propósitos ao submeter a vida, os sonhos e a esperança de milhares de trabalhadores e trabalhadoras pauperizados aos princípios da acumulação. É, inclusive, esse comportamento que, a nosso ver, continua mantendo o processo de expropriação dos trabalhadores rurais em nossos dias.

\section{Referências}

ANTUNES, R. Ensaio sobre a afirmação e a negação do trabalho. 4. ed. São Paulo: Boitempo, 2001.

ARENDT, H. A condição humana. 7. ed. Rio de Janeiro: Forense Universitária, 1995.

CARNEIRO, M $^{\mathrm{a}}$ J. Ruralidade: novas identidades em construção. Estudos Sociedade e Agricultura, 11, p. 53-75, out, 1998. Disponível em: http://bibliotecavirtual.clacso.org.ar/ar/libros/brasil/cpda/estudos/onze/zeze11.htm. Acesso em: 01/04/2011.

DAMIANI, A. L. População e geografia. 5. ed. São Paulo: Contexto, 2001. 
FARAH, M. F. S. Processo de trabalho na construção civil: tradição e mudança. São Paulo: ANNABLUME, 1996.

FRIGOTTO, G. Educação e a crise do capitalismo real. São Paulo: Cortez, 1995.

GAUDEMAR, J. P. de. Mobilidade do trabalho e acumulação do capital. Lisboa: Estampa, 1977.

GOMES, F. G. Mobilidade do trabalho e controle social: trabalho e organização na era neoliberal. Revista de Sociologia e Política, v.17, n. 32, p.33-49, 2009. Disponível em: www.scielo.br/scielo.php?pid=S0104-44782009000100003\&script=sci_arttext.

Acesso em: 12/05/2014.

HEYDORN, H.J. Elementos de uma teoria da educação. Tempo Brasileiro Revista de cultura a crise do pensamento moderno 1, n. 17/18, 1968.

IANNI, O. Origens Agrárias do Estado Brasileiro. SP: Brasiliense, 2004.

INSTITUTO BRASILEIRO DE GEOGRAFIA E ESTATÍSTICA (IBGE). Censos demográficos do Brasil - Bahia, 1940, 1950, 1960, 1970, 1980, 1991, 2000 e 2010.

INSTITUTO DE PESQUISA ECONÔMICA APLICADA. Caracterização e tendências da rede urbana do Brasil. Brasília: IPEA, 1999.

LUKÁCS, G. As bases ontológicas do pensamento e da atividade do homem. Temas de Ciências Humanas. São Paulo: Livraria Editora Ciências Humanas, 1978.

MARTINS, J. S. Exclusão social e a nova desigualdade. S.P.: Paulus, 2012.

MARX, K. O Capital - Crítica da Economia Política. In: Coleção “Os economistas". Tradução de Regis Barbosa e Flávio R. Kothe. 2. ed. São Paulo: Nova Cultural, 1985. v. 1.

A origem do capital. A acumulação primitiva. 6. ed. Tradução de Walter S.

Maia. São Paulo: Global Editoras, 1989.

MENEZES, S. O. Entre o campo e a cidade: trabalho e trabalhadores dentro do território de luta. In: CONCEIÇÃO, A. L. (Org). Trabalho e trabalhadores: as novas configurações espaciais da reestruturação produtiva no espaço rural. São Cristóvão/SE: Editora UFS,2011.

NOSELLA, P. Trabalho e Educação. In: GOMEZ, C. et al. Trabalho e Conhecimento: Dilemas na Educação do Trabalhador. 2. ed. São Paulo: Cortez; Autores Associados, 1989.

OLIVEIRA, F. A economia Brasileira: crítica à razão dualista. 4 ed. Petrópolis, RJ: Vozes, 1981. 
SAMPAIO, A. V. O. Mobilidade do trabalho e produção do espaço regional de Vitória da Conquista - BA. São Cristóvão/SE, 2013. Tese de Doutorado na Universidade Federal de Sergipe (UFS), 2013.

SILVA, J. G. A nova dinâmica da agricultura brasileira. 2 ed. SP: IE/Unicamp, 1998.

SILVA, M. A. de M. Errantes do fim de século. São Paulo: Fundação editora da UNESP, 1999.

SOUZA, S. T.; SANTOS, J. R. D. Considerações sobre a mobilidade do trabalho na relação campo-cidade em Vitória da Conquista. Vitória da Conquista: Anais do VIII Encontro Baiano de Geografia e X Semana de Geografia da UESB, 2011. ISSN 21794774. Disponível em: www.uesb.br/eventos/ebg/anais/8g.pdf. Acesso em 07 de abril de 2014.

VARGAS, N. Tendências de mudança na indústria da construção. Espaço \& Debates: Trabalho e construção da cidade. São Paulo: Núcleo de Estudos Regionais e Urbanos, Ano XXII, n³6, p.47-53, 1992.

WANDERLEY, Ma de N. B. O mundo rural como um espaço de vida: reflexões sobre a propriedade da terra, agricultura familiar e ruralidade. Porto Alegre: UGRGS, 2009.

WANDERLEY, M ${ }^{\mathrm{a}}$ de N. B. A emergência de uma nova ruralidade nas sociedades modernas avançadas - o "rural" como espaço singular e ator coletivo. Estudos Sociedade e Agricultura, 15, p. 87-145, out, 2000. Disponível em: http://agriculturasamazonicas.ufpa.br/PDF'S/AA_selecao/2011/Wanderley\%201996.pdf; Acesso em: 01/04/20011.

\footnotetext{
${ }^{1}$ Doutora em educação. Docente do Departamento de Filosofia e Ciências Humanas e do Programa de PósGraduação em Memória, Linguagem e Sociedade, da Universidade Estadual do Sudoeste da Bahia - UESB. Membro do Museu Pedagógico da UESB. ana_alves183@hotmail .com

${ }^{2}$ Mestre em Geografia. Docente do Departamento de Geografia da Universidade Estadual do Sudoeste da Bahia - UESB. Doutoranda do Programa de Pós-Graduação em Memória, Linguagem e Sociedade da UESB. miriamclea@gmail.com

${ }^{3}$ Projeto de pesquisa que está sendo desenvolvido pelo grupo de estudos História, Trabalho e Educação do Museu Pedagógico da UESB. Projeto financiado pela Fundação de Amparo à Pesquisa do Estado da Bahia (FAPESB).
}

Recebido em abril-2014

Aprovado em maio-2014 